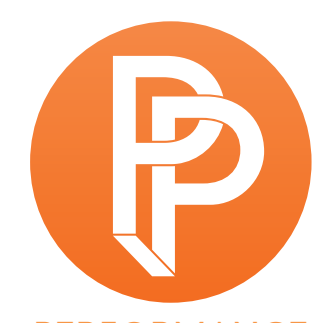

PERFORMANCE

PHILOSOPHY

\title{
DIALECTIC OF RESTLESSNESS
}

\section{MARCUS STEINWEG BERLIN UNIVERSITY OF THE ARTS}

\section{WASTELAND}

The fact that humanity jumps from the past like a wounded animal doesn't mean that it escapes it. Jumping out of the old into the new confirms the former as the shore of the latter. It's a leap into the unknown that succeeds if the subject jumps back to the shore to experience it as the true ocean of inconsistency. The past is fragmentary and incoherent. Not even alienation is reliable. No island remains. No childhood comfort. No memory that isn't an illusion. No word that doesn't lie. There's nothing but a wasteland, indistinguishable from the indifference of the sea. The fact that the sea is "at once the symbol of the impossibility and the possibility of the event" (Badiou 2014, 418), ${ }^{1}$ says Badiou, means that it unites the expanses of immanence with the transcendencies that tear it apart. As in the human subject, the horizontal and the vertical intersect on the sea. Which is why Deleuze could evoke it as a zone of eruptive vertical unrest. At times it stands for self-explanatory indifference, at other times for aggressive self-interruption. It perpetuates that which is, indicating it as abyss in the process. It is a metaphor for the rift in being-which Lacan calls the real, Deleuze chaos, Badiou the event-as the break with itself in the texture of being. Thus it exemplifies immanent transcendence. ${ }^{2}$ 


\section{BODY}

The fact that what we call life does not include dead material can't conceal the fact that it proliferates within the living, as if death mushroomed within life, which led Friedrich Kittler to speak of the "fathomless depths of the body" (Kittler 2011, 45). ${ }^{3}$ Agamben is right-he riffs here on a statement from Derrida's Specters de Marx-that the question of life-What is life?-plunges the thinking of "our culture" (Agamben 2004, 13) (that is, western culture) at least into the greatest of difficulties. Maybe this question is exemplary of the aporetic condition of all thought that abandons empirical description as well as formal logical deduction in order to turn to metaphysical problems. It is insufficient to fall in with the usual condemnations, dismissals, and deconstructions of metaphysics and ontology in order to elude the experience of the body's dizzying depths. With the body, through it, the human subject is connected to its animality as well as the experience of exceeding it. The body proves to be the theater of thought. The dust of dead stars swirls and accumulates within it, the memory of dead material, the history of its genetic disposition. The living body, it would seem, before it sets about thinking or reflecting consciously, demonstrates itself to be the archive of humanity, as fathomless as it is fragmentary. It stretches far beyond the humanwhich remains one monstrous dimension-into ancient unconscious material. In it, the forgotten as well as the never-remembered aggregates. Instead of just being the museum and the ruin of a history of consciousness, it also exhibits the unconscious and never-conscious of this history. It exposes what the memory of the species has evaded. But it's a piecemeal and encrypted exposition. With the question of the body, the subject addresses the question of its obscure past. We can call it fathomless because it stretches into the abyss of memory, which is the abyss of thought, a depth that remains bottomless.

\section{WRITING}

The "central experience" of writing poetry-and doubtlessly also philosophy-is supposed to lie in the "margin between truth and its transmission" (Agamben 1993, 147) according to Giorgio Agamben, as if truth were the name of the untransmittable par excellence. The problematic thing about this view is that it measures the "object" known as truth by the ideal of how objectifiable it is. A progressive conception of truth must free itself from this ideal by indicating something other or more than just its unredeemabilit. Instead of standing in opposition to transmission, truth is the name for the margin between the impossible object and the attempt to objectify it. That makes the truth into the real of reality, to put it in Lacanian terms. Truth isn't the failed object of poetry or thought, but rather the reality of this failure as every subject's normality. There is no concept that is less sublime or mysterious. The truth is what was always present: the ontological inconsistency of the subject and its reality.

\section{CHAOS}

In 1861, the 17-year-old Nietzsche wrote a school assignment on Hölderlin, in which he defended the poet by invoking his luminous moments, wrung from "the advancing night of madness" 
(Nietzsche 2001, 49). ${ }^{4}$ Which didn't keep his teacher from advising him "'[...] to stick to a healthier, clearer, more German poet"' (Kaufmann 1974, 23). Nietzsche wouldn't abandon Hölderlin, even if he later increasingly turned to Goethe. In Human, All-Too-Human there is a comment titled The Treasure of German Prose: "Apart from Goethe's writings and especially the conversations with Eckermann (the best German book in existence) what German prose literature remains that is worth reading over and over again? Lichtenberg's Aphorisms, the first book of Jung-Stilling's Story of My Life, Adalbert Stifter's St. Martin's Summer and Gottfried Keller's People of Seldwyla-and there, for the time being, it comes to an end" (Nietzsche 2006, 400). Nietzsche's Goethe-philia is connected to his enthusiasm for Stifter's St. Martin's Summer (1857) because he sees the Dionysian wellspring, the nocturnal chaos beneath the surface of form and idylls, signaled instead of suffocated. Which is why Walter Kaufmann could claim that the concept of the Dionysian in the late Nietzsche represents the alliance of Dionysus and Apollo, which Nietzsche legitimated in defense of the "Dionysian faith of Goethe" (Kaufmann 1974, 323). If we associate the categories of light and dark or day and night with the opposition of Apollo and Dionysus, then it's insufficient to see them reflected in the difference of Weimar classicism, with all of its possible variations of "dark romanticism" (including Hölderlin and Kleist). The difference gets lost in the heart of this position, as it articulates the dialectic of light and dark without exception. Perhaps dialectic-in its Platonic and Hegelian variations, from Heidegger's primal struggle between lethe and aletheia, hiddenness and unhiddenness, to Adorno's negative dialectic-is always concerned with the conflict between evidence and lack of evidence, day and night, the visible and the invisible.

\section{VANISHING POINT}

Thought's vanishing point isn't located in what exists. Thinking means breaking rank with what exists. Not in order to indulge in the imaginary. To withdraw from the existing is to exit the fiction known as reality. Does that mean that there are no realities? It means that the things we refer to as such lack any validity. Thinking implies the experience of the world's invalidity. The cosmos is incommensurable. It doesn't have any value. Not closing one's mind to cosmic indifference is part of the basic experience of philosophy.

\section{SCRAPHEAP}

First there is debris, unordered material, chaos. Heraclitus knew that: "The fairest universe is but a heap of rubbish piled up at random" (Heraclitus 1994, n.p.). From this point on, the dialectic of order and chaos will dominate western thought. It extends to Heidegger's "primal struggle" between "world" and "earth," in which the conflict between openness and closing or aletheia and lethe finds expression. Heiner Müller associates it with Foucault, by alleging that the ancient Greeks had a "measure" for the incommensurable, a knowledge of the irreducibility of chaos: "the cosmos as a scrapheap is still the most likely theory" (Müller 2008, 843). ${ }^{5}$ 


\section{BREATHING}

In To Write in a Foreign Language, Etel Adnan compared the act of writing with breathing: "My own writing," she says reminiscing in this text, which originally appeared in English in 1984, "was like my own breathing: something I was doing" (Adnan 1985). Writing as breathing, writing that has the same evidence as breath. Maybe you could add that writing also entails a certain amount of breathlessness. Writing should have the naturalness and necessity of the breathing that keeps the subject alive. The subject resists the thought of a life without writing. We often hear authors say that they couldn't live without writing. Maybe what they mean by that is: I live to write, and I write to live/survive. The nexus of life and writing is the index of their reciprocity and their conflict.

\section{CREATION}

In II fuoco e il racconto (orig. 2014), Agamben says that the act of creation is determined by the "twofold structure" of two contradictory forces: "thrust [élan] and resistance, inspiration and critique" (Agamben 2017, 43). That leads him to the basic dialectical experience of artistic-as well as scientific and philosophical-creation. The subject always finds itself in a state of agitation that causes it to fluctuate between impulsiveness and method, haste and stagnation, proflecton and reflection. The fire that artists kindle in the heart of established realities must encompass the entire dialectic of agitation, instead of just being the ember of passion. Instead of simply differentiating between the mystery and the story, as Agamben does, we should recognize a flame in their contentious compossibility, which feeds philosophy and science, poetry and art, in that they employ inspiration and criticism to the same degree. That's what's meant by the resistant nature of the act of creation: the refusal to sacrifice criticism to inspiration or proflection to reflection. Actually, élan and resistance, passion and calculation, excess and precision all go hand-in-hand. A work of art is moving when it succeeds in uniting both sides, exposing its conflict as well as the difficulties of mediating it. The resistant nature of the act of creation entails the struggle against the idealistic varnishing of its artificial character, its adhesion to the existing, as well as its belonging in the world. The work is autonomous in that it exposes its heteronomy. It itself is exhibition, even before it is put on display: exhibition of the fire it ignites, exhibition of the means and forms of its articulation. Exhibition of its resistance to the normalcy which it never stops being a part of.

\section{UNRECONCILED}

The claim that "the work of art [...] loses all value" when the artist "in any way attempts to insinuate a reconciliation with the human situation and world condition" into it, comes from Friedrich Hebbel (Hebbel 1905, 233). ${ }^{6}$ Though irreconcilability is part of the work of art, that doesn't mean that it exhausts itself in negativity, the pathos of the critical, or in wounded defensiveness. Distancing yourself from resentment and victimization is part of art. Its style of attack is characterized by assertiveness and confident affirmation of the incommensurable. Completely immersed in world affairs, fully confronting the aporia of human existence, the work of art is the arena of controversial humor. In all significant works of art, laughter at the futility of our constructions of meaning 
triumphs, at the critical remorse of those who style themselves victims of their realities. Which is why Adorno could imagine the compossibility of the reconcilable and irreconcilable. Dialectic can only begin with the interweaving of the two terms. Like Hebbel, Adorno doesn't consider pursuing a dialectic of reconciliation which (right or wrong) is associated with Hegel's absolute idealism and whose function lies in a reactionary arrangement with developments in the world: "The reconciled condition would not be the philosophical imperialism of annexing the alien. Instead, its happiness would lie in the fact that the alien, in the proximity it is granted, remains what is distant and different, beyond the heterogeneous and beyond that which is one's own" (Adorno 1973, 191). The irreconcilable reconciliation that Adorno-and Hebbel, in his way-suggests is the affirmation of the distant and the various as an incommensurable measure, in that they cannot be identified, marking the truth of our world as nonidentical.

\section{TWO KINDS OF OBSCURANTISM}

In the section of Aktive Passivität (2014) entitled Ästhetik des Nichtwissens (The Aesthetic of Unknowing) Martin Seel follows Adorno's formulation of "determinate indeterminateness" in order to proclaim the "celebration of unknowing" as the "telos of all aesthetic perception" (Seel 2014, 102-104). ${ }^{7}$ He's undoubtedly right that uncertainty and unknowing are part of experiencing a work of art as well as aesthetic reflection. Adorno's formulation restricts the dimensions of the certain and the uncertain, the known and the unknown, the determinate and the indeterminate. Everything depends upon grasping the character of this restriction. You can speak of dialectic insofar as it remains a negative dialectic that denies itself a final synthesis. It's a dialectic of restlessness, in which the two corresponding poles abrade each other. The indeterminate is threatened by the determinate and vice-versa. Initially, this mutual threat vitalizes both dimensions. They are what they are only through the contentious mediation of their opposite. This unrest is the measure of the progressive character belonging to this relationship of unrest, which also means that artistic thought and aesthetic reflection must escape these two forms of quietism: the obscurantism of unknowing, as well as the obscurantism of knowing. There is no complete knowing and no total unknowing. What we call art is resistance to this double obscurantism. Therefore, the expression the "celebration of unknowing" is misleading. Neither unknowing nor knowing is celebrated-if you can speak of celebration at all. It's this impossibility of privileging the one over the other, of making their relationship hierarchical, which is expressed in a work of art. The work of art is the theater of elementary resistance. If it celebrates anything, it's this impossibility. Art denies itself obscurantism, quietism, and dialectical synthesis. And therefore it also denies itself celebration and self-celebration. Art looks soberly on realities that elude its gaze. You can speak of a certain coldness of the gaze or of "controlled insanity" (see: Müller 2014). The work of art constitutes the scene of the subject's becoming. In it, reflection mingles with obscurantism, analysis with passion, intellect with affect, criticism with affirmation. None of the

poles leaves the others in peace. Only in their polemical restriction and reciprocal irritation is there the possibility for art. 
1 "[La mer] est le symbole, à la fois, de l'impossibilité et de la possibilité de l'événement." Passage translated from French to English by Marcus Steinweg.

2 It's a mistake to think that contemporary thought has settled into immanence. Thinking is unsettled thinking because it does not allow itself this ease. Though earlier philosophy seemed to have set the subject on the track of a metaphysics of pacification and happiness-in-unhappiness dialectic, whose collateral was a certain concept of transcendence that assured the existence and consistency of a transcendental signifier, the thought of modernity-and here Hegel is the watershed, half happiness-in-unhappiness dialectician, half sad proto-Adornian metaphysician-found itself ever more rapidly exposed to the inexistence of such an entity. The anti-Platonicism as well as the anti-Hegelianism of a large portion of the philosophy of the twentieth century generated this increased unrest of a transcendentally homeless subject who finds no orientation in the desert of immanence other than its own lack of orientation. Now-and Nietzsche essentially already said this_everything depends on not making a new god out of this subject of immanence's lack of orientation: the god of nihilism, or of the last man, which tends toward a religion of immanence. Immanence isn't absolute. It has holes that you can call points of transcendence or inconsistency, as long as these concepts are understood as formal, a-religious terms for naming the ontological incompleteness of the fabric of immanence that is our reality. The point is not to reintroduce transcendence into immanence, as reactionary political and fundamental religious ideologies demand. The point is to show that the substitution of transcendental metaphysics with a religion of immanence remains trapped in the model of seamless continuity and necessity. A "new dialectic between the finite and the endless" (Badiou 2015, 10, passage translated from French by Marcus Steinweg) would have the function of intellectually formalizing the immanence of transcendence, or as Badiou puts it, the "immanence of truths." (L'immanence des vérités is the title of the forthcoming third part of the outline of his mathematical ontology, together with the 1988 L'être et l'événement and the 2006 Logiques des mondes.)

3 Passage translated from German to English by Marcus Steinweg.

4 "Wenn [...] der Tiefsinn mit der einbrechenden Nacht des Wahnsinns ring [...]." Passage translated from German to English by Marcus Steinweg.

5 "[...] der Kosmos als Schrotthaufen ist die wahrscheinlichste Theorie." Passage translated from German to English by Marcus Steinweg.

6 "[...] wenn der Dichter seinem Kunstwerk eine Versöhnung mit der menschlichen Situation und den Weltzuständen überhaupt, einzuhauchen sucht [...]. Mir scheint, daß das Kunstwerk dann jeden Werth verliert." Passage translated from German to English by Marcus Steinweg.

7 Passage translated from German to English by Martin Steinweg.

\section{Works Cited}

Adnan, Etel. 1985. "To Write in a Foreign Language." In Unheard Words, edited by Mineke Schipper. London: Allison \& Busby.

Adorno, Theodor. 1973. Negative Dialectics. Translated by E. B. Ashton. London: Routledge.

Agamben, Giorgio. 1993. Infancy and History: The Destruction of Experience. Translated by Liz Heron. London: Verso. 2004. The Open: Man and Animal. Translated by Kevin Attell. Stanford: Stanford University Press.

2017. The Fire and the Tale. Translated by Lorenzo Chiesa. Stanford, California: Stanford University Press.

Badiou, Alain. 2014. Images du temps présent, Le Séminaire 2001-2004. Paris: Fayard.

2015. Métaphysique du bonheur réel, Paris: Presses Universitaires de France. 
Hebbel, Friedrich. 1905. Sämtliche Werke. Tagebücher 1845-1854, Bd. 3. Edited by Richard Maria Werner. Berlin: Behr.

Heraclitus. 1994. Heraclitus. The Complete Fragments. Translated by William Harris. Middlebury: Middlebury College. Kaufmann, Walter. 1974. Nietzsche, Philosopher, Psychologist, Antichrist. Princeton: Princeton University Press.

Kittler, Friedrich. 2011. Das Nahen der Götter vorbereiten. Paderborn: Wilhelm Fink.

Müller, Heiner. 2008. Gespräche 3: 1991-1995. Werke 12. Frankfurt: Suhrkamp.

2014. Theater ist kontrollierter Wahnsinn. Herausgegeben und mit einem Vorwort von Detlev Schneider. Berlin: Alexander Verlag.

Nietzsche, Friedrich. 2001. "Schulaufsatz über Hölderlin." In Hölderlin und Nietzsche. Zwei Aufsätze, herausgegeben von Theobald Ziegler und Klaus H. Fischer, 47-51. Schutterwald/Baden: Wissenschaftlicher Verlag.

2006. Human, All-Too-Human. Translated by Paul V. Cohn and Helen Zimmer. New York: Dover.

Seel, Martin. 2014. Aktive Passivität. Frankfurt am Main: Fischer.

\section{Biography}

Marcus Steinweg, born in Koblenz in 1971, is a philosopher and author living in Berlin. Over several years he cooperated with the artists Thomas Hirschhorn and Rosemarie Trockel. In 2014/2015 visiting professor for contemporary media at the Hochschule für bildende Künste Hamburg. In 2008/2009 lecturer at the Hochschule für Bildende Künste Braunschweig. For the Merve publishing house he edits the Inaesthetics journal which operates at the interface of arts and philosophy and presents contributions in German, English and French.

(c) 2017 Marcus Steinweg

cc) (†) Except where otherwise noted, this work is licensed under a Creative Commons Attribution-

cc) ${ }_{\mathbf{B Y}} \mathbf{N C}_{\mathbf{S A}}$ NonCommercial-ShareAlike 4.0 International License. 